\title{
The Lichenologist
}

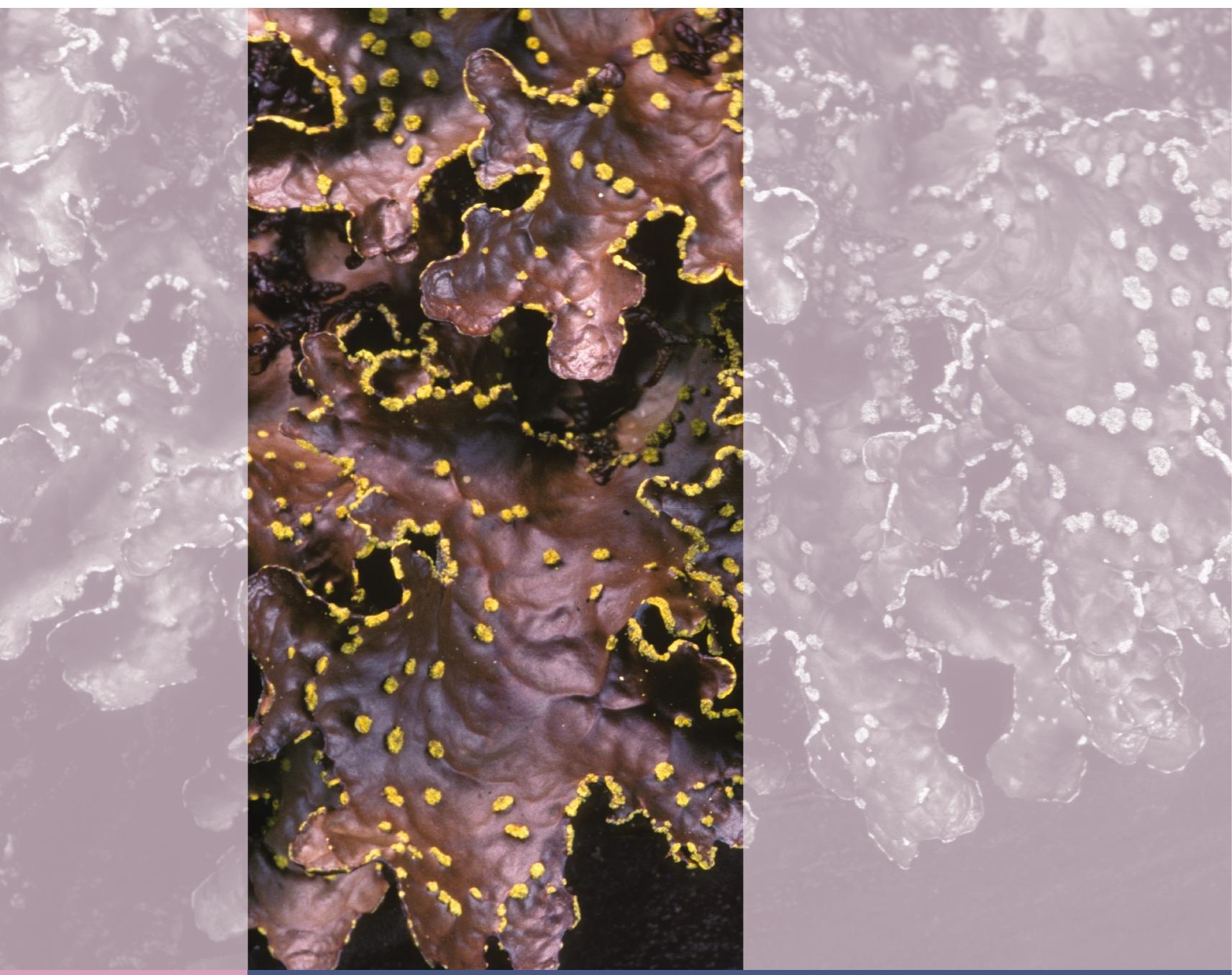




\title{
The Lichenologist
}

\author{
AN INTERNATIONAL JOURNAL \\ Published for the British Lichen Society \\ Senior Editor \\ P. D. CRITTENDEN (Nottingham, UK)
}

Editors

\author{
A. F. BRAITHWAITE-Managing \\ (Nottingham, UK) \\ R. P. BECKETT (Scottsville, RSA) \\ B. J. COPPINS (Edinburgh, UK) \\ A. CRESPO (Madrid, Spain) \\ P. DIEDERICH (Luxembourg) \\ S. EKMAN (Uppsala, Sweden) \\ D. ERTZ (Meise, Belgium) \\ A. M. FRYDAY (East Lansing, USA) \\ D. J. HILL-Book Reviews (Bristol, UK)
}
J. D. LAWREY (Fairfax, USA)
R. LÜCKING (Chicago, USA)
L. MYLLYS (Helsinki, Finland)
A. ORANGE (Cardiff, UK)
S. PÉREZ-ORTEGA (Madrid, Spain)
C. PRINTZEN (Frankfurt, Germany)
T. SPRIBILLE (Graz, Austria)
M. WEDIN (Stockholm, Sweden)
S. WILL-WOLF (Madison, USA)
R. YAHR (Edinburgh, UK)

\section{AIMS AND SCOPE}

The Lichenologist publishes original research papers and review articles on all aspects of lichenology. There are no page charges for contributions. All papers are submitted to peer-review.

\section{SUBMISSION OF MANUSCRIPTS}

Manuscripts must be original, clearly and precisely presented in English and submitted electronically to The Lichenologist ScholarOne website $\mathrm{http}: / / \mathrm{mc}$.manuscriptcentral.com/lich following the on-screen instructions. Please consult the Instructions for Authors published in the back of each issue and on journals.cambridge.org/lic

\section{ADVERTISING}

Address enquiries in the USA, Mexico and Canada only to: journals_advertising@cup.org

For all other parts of the world except USA, Canada and Mexico to: ad_sales@cambridge.org

\section{SUBSCRIPTIONS}

The Lichenologist (ISSN 0024-2829) is published six times a year (one volume per annum) in January, March, May, July, September and November. Volume 46 will appear in 2014 . The 2014 subscription price (excluding VAT but including delivery by air where appropriate) of a volume, which includes print and electronic access to institutions, is $£ 877$ (US $\$ 1591$ in USA, Canada and Mexico). The electronic-only price available to institutional subscribers is $£ 644$ (US $\$ 1160$ in USA, Canada and Mexico). The print-only price available to institutional subscribers is $f 798$ (US $\$ 1450$ in USA, Canada and Mexico). Single parts are $£ 145.30$ (US $\$ 265.83$ in USA, Canada and Mexico) plus postage. EU subscribers (outside the UK) who are not registered for VAT should add VAT at their country's rate. VAT registered members should provide their VAT registration number.

Orders, which must be accompanied by payment, may be sent to any bookseller, subscription agent or direct to the publisher: Cambridge University Press, The Edinburgh Building, Shaftesbury Road, Cambridge CB2 8RU, UK; or in the USA, Canada and Mexico: Cambridge University Press, Journals Fulfillment Department, 100 Brook Hill Drive, West Nyack, New York 10994-2133.

Fapanese prices for institutions (including ASP delivery) are available from Kinokuniya Company Ltd, P.O. Box 55, Chitose, Tokyo 156, Japan. Prices include delivery by air.

Periodicals postage paid in New York NY and additional mailing offices.

Postmaster: send address changes in USA, Canada and Mexico to: The Lichenologist, Cambridge University Press, 100 Brook Hill Drive, West Nyack, New York 10994-2133.

Claims for a missing issue should be made immediately on receipt of the subsequent issue.

\section{COPYRIGHT AND PERMISSIONS}

This journal is registered with the Copyright Clearance Center, 222 Rosewood Drive, Danvers, MA 01923, USA. Organizations in the USA who are also registered with C.C.C. may therefore photocopy material (beyond the limits permitted by Section 107 and 108 of US Copyright law) subject to payment to C.C.C. of the per-copy fee of $\$ 16.00$. This consent does not extend to multiple copying for promotional or commercial purposes. Code 0024-2829/2014 \$16.00. ISI Tear Sheet Service, 3501 Market Street, Philadelphia, PA 19104, USA, is authorised to supply single photocopies of separate articles for private use only. Organizations authorised by the UK Copyright Licensing Agency may also copy material subject to the usual conditions. For all other use, permission should be sought from Cambridge University Press. No part of this publication may otherwise be reproduced, stored or distributed by any means without permission in writing from Cambridge University Press.

Copyright (C) 2014 British Lichen Society

\section{OPEN ACCESS}

The Lichenologist now offers an Open Access option

For further information see http://journals.cambridge.org/lic

\section{ELECTRONIC ACCESS}

This journal is included in the Cambridge fournals Online service which can be found at journals.cambridge.org. Further information on this and other Cambridge University Press titles is available on the Cambridge University Press homepage at www.cambridge.org.

Cover photograph: Pseudocyphellaria crocata by Stephen and Sylvia Sharnoff.

\section{Cambridge University Press}

The Edinburgh Building, Shaftesbury Road, Cambridge CB2 8RU, United Kingdom

32 Avenue of the Americas, New York, NY 10013-2473, USA

477 Williamstown Road, Port Melbourne, VIC 3207, Australia

Ruiz de Alarcón 13, 28014 Madrid, Spain

Dock House, The Waterfront, Cape Town 8001, South Africa

Printed in the United Kingdom by Henry Ling Limited, at the Dorset Press, Dorchester, DT1 1HD 